\title{
Allometric Models for Aboveground Biomass of Six Common Subtropical Shrubs and Small Trees
}

\section{Cheng Huang}

Anhui Agricultural University https://orcid.org/0000-0002-4163-745X

\section{Chun Feng}

Anhui Agricultural University

\section{Yuhua Ma}

Anhui Agricultural University

\section{Hua Liu}

Anhui Agricultural University

\section{Zhaocheng Wang}

Anhui Agricultural University

\section{Shaobo Yang}

Anhui Agriculture University: Anhui Agricultural University

\section{Wenjing Wang}

Anhui Agricultural University

\section{Songling Fu}

Anhui Agricultural University

Han Y. H. Chen ( $\sim$ hchen1@lakeheadu.ca )

Anhui Agricultural University https://orcid.org/0000-0001-9477-5541

Research

Keywords: aboveground biomass, allometric models, shrubs; small trees, subtropical forests

Posted Date: June 8th, 2021

DOI: https://doi.org/10.21203/rs.3.rs-573830/v1

License: (c) (i) This work is licensed under a Creative Commons Attribution 4.0 International License. Read Full License 


\section{Abstract}

Background: The aboveground biomass (AGB) of shrubs and small trees is the main component for the productivity and carbon storage of understory vegetation in subtropical natural secondary forests. However, few allometric models exist for shrubs and small trees, even though they can accurately evaluate understory vegetative biomass.

Methods: To estimate the ABG of six common shrub and small tree species, we utilized harvesting to sample 206 individuals, and developed species-specific and multi-species allometric models based on four predictors including height $(\mathrm{H})$, stem diameter (D), crown area (Ca), and wood density $(\rho)$.

Results: As expected, these six shrub and small tree species possessed greater biomass in their stems in contrast to branches, with the lowest biomass in the leaves. Species-specific allometric models that employed D and the combined variables of $D^{2} \mathrm{H}$ and $\rho \mathrm{DH}$ as predictors, could accurately estimate the components and total $A G B$, with $R^{2}$ values ranging from between 0.602 and 0.971 . A multi-species shrub allometric model revealed that $\rho D H$ was the best predictor, with $R^{2}$ values ranging from between 0.809 and 0.890 .

Conclusions: These results indicated that $\mathrm{H}$ and $\mathrm{D}$ were effective predictors for the models to estimate the AGB of the six shrub and small tree species, and the introduction of $\rho$ improved their accuracy. The optimal model selected in this study could be applied to estimate the biomass of shrubs and small trees in the subtropical regions.

\section{Introduction}

Shrubs (stem ramifications $<1.3 \mathrm{~m},<5 \mathrm{~m}$ high) and small trees (stem ramifications $>1.3 \mathrm{~m},<8 \mathrm{~m}$ high) (Mbow et al. 2014, Bayen et al. 2020) are important components of understory vegetation (MacDonald et al. 2012, Flade et al. 2020). Shrubs and small trees are the main carbon sinks of forest vegetation, particularly in the early stages of forest stand succession, which can quickly absorb and release nutrients within the soil, thereby accelerating the carbon cycle between vegetation and soil (Cavard et al. 2011, Kumar et al. 2018). Consequently, an accurate assessment of the biomass of shrubs and small trees is critical for the estimation of carbon storage in ecosystems.

The most accurate technique for estimating the biomass of individual trees or shrubs is direct harvesting and weighing. However, this strategy is only suitable at a small-scale due to its being labor intensive and time-consuming (MacDonald et al. 2012, Ali et al. 2015). Furthermore, the large-scale harvesting of shrubs and small trees reduces vegetation coverage, increases the risk of soil erosion, and destroys wildlife habitats (Cavard et al. 2011, Donato et al. 2012, Brantley et al. 2016). Allometric models with easily measurable predictors can be used to quickly estimate the aboveground and belowground biomass of plants without damaging them (Djomo et al. 2010, Roxburgh et al. 2015, Bayen et al. 2020, Brassard et al. 2011).

As the primary component of forest carbon storage, large trees have been studied by many researchers toward the establishment of allometric models (Cairns et al. 2009, Cavanaugh et al. 2014, Jagodzinski et al. 2019). Due to the morphological differences in growth between large trees, small trees, and shrubs, large tree equations are not suitable for calculating the biomass of shrubs and small trees (Bond-Lamberty et al. 2002). Consequently, it is necessary to generate allometric equations that can approximate their biomass (Chave et al. 2005).

When estimating the biomass of multi-branched shrubs, stem height $(\mathrm{H})$ is typically regarded as a quantifiable measurement factor for the development of allometric equations (Chaturvedi et al. 2013, Chave et al. 2014). Some researchers have also considered the stem diameter (D) and crown area (Ca) of shrubs, whereas others have included the combined variable, $\mathrm{D}^{2} \mathrm{H}$, as a predictor (Elzein et al. 2011, Liu et al. 2015, Huff et al. 2018). Moreover, the addition of wood density ( $\rho$ ) might significantly improve the estimation of tree biomass (Ali et al. 2015). In particular, generalized allometric models that included $\mathrm{D}, \mathrm{H}$, and $\rho$ have been reported to have more stability and less uncertainty, particularly for mixed species models (Alvarez et al. 2012).

Loading [MathJax]/jax/output/CommonHTML/jax.js 
Generally, the regression equation of a biomass allometric model is constructed by employing power (Paul et al. 2013), linear, and power exponential functions (Sharma et al. 2011, Dou et al. 2019) with measurement factors as variables. Nonlinear models are more likely to accurately fit the relationship between the measurement factors and biomass than linear models (Chapagain et al. 2014).

The objective of this study was to develop species-specific and multi-species allometric models for the prediction of branch, stem, leaf, and total aboveground biomass for the most dominant species of the forest understorey in subtropical China. To ensure the accuracy of the models, we measured as many samples (206) of shrubs and small trees as possible when collecting data. When developing models, we selected single variable $\mathrm{D}, \mathrm{H}, \mathrm{Ca}, \rho$, and complex variables $\mathrm{D}^{2} \mathrm{H}$ and $\rho \mathrm{DH}$ and compared the resulting models for their predictive power.

\section{Materials And Methods}

\subsection{Study Area}

The plant component AGB was derived from shrubs and small trees growing in the natural secondary forests of Qiaomu Township, located $22 \mathrm{~km}$ northeast of Qingyang County $\left(30^{\circ} 19^{\prime} \mathrm{N}\right.$ to $30^{\circ} 50^{\prime}$ and $117^{\circ} 40^{\prime}$ to $\left.118^{\circ} 07^{\prime} \mathrm{E}\right)$, in Anhui Province, China. This region is home to a subtropical humid monsoon climate with average temperatures of $28^{\circ} \mathrm{C}$ and $3^{\circ} \mathrm{C}$ during the summer and winter months, respectively, which is suitable for the support of a rich and sustainable carbon sink (Yu et al. 2014). The elevation of this area ranges from $44.6-104.1 \mathrm{~m}$, with an average annual precipitation of $1374.7 \mathrm{~mm}$. The soil type is brown calcareous (IUSS Working Group WRB 2014) and the thicknesses ranges from $20 \mathrm{~cm}$ to $100 \mathrm{~cm}$.

The vegetation type of the study area is subtropical deciduous broadleaved forest, and the typical overstorey is dominated by Liquidambar formosana, Quercus acutissima Carruth, and Castanea mollissima. Common understorey shrubs and herbaceous species in the study area include Lindera fruticosa, Diospyros rhombifolia, Acer ginnala, Liriope graminifolia, Liriope muscari, and Microlepia marginata.

\subsection{Sampling design}

Five shrub species (Acer ginnala, Diospyros rhombifolia, Rhododendron ovatum, Camellia cuspidate, and Lindera fruticosa) and one small tree species (Dendrobenthamia japonica), which are widely distributed in subtropical natural secondary broadleaved mixed forests, were selected to develop allometric biomass models. We sampled 24 stands from natural secondary broadleaved mixed forests following the cessation of anthropogenic disturbances (e.g., selective harvesting, firewood collection, and grazing) to allow for regrowth (Yang et al. 2021). In each stand, we established a $20 \times 20 \mathrm{~m}^{2}$ plot and the distance between the sample plots was $>100 \mathrm{~m}$. For each species, we selected $\sim 35$ individuals and a total of 206 individuals of six species from the 24 plots. Individuals were selected to represent the range of heights and diameters of the entire population as closely as possible. All field surveys were conducted in mid-August 2020.

\subsection{Field data collection}

Prior to the harvesting of any shrub or small tree, we measured the height $(\mathrm{H})$, crown area (Ca), and stem diameter (D). H was defined as the distance between the ground and the highest point of the canopy. Ca encompassed two directions, the maximum diameter of the crown (d1), and perpendicular diameter to d1 (d2).

$\mathrm{Ca}=\pi \times \frac{d 1 \times d 2}{4}(1)$

D was different for shrubs and small trees, where the stem diameter was measured at $130 \mathrm{~cm}$ and $10 \mathrm{~cm}$ above the root collar for small trees and shrubs, respectively. Each harvested sample was separated into stems, branches, and leaves, stored in sealed bags, and then transferred to the laboratory for analysis within three days. 
All laboratory analyses were completed at Anhui Agricultural University in Heifei, Anhui, China. The fresh weight $(0.01 \mathrm{~g})$ of each component was measured using an electronic balance. To determine the specific wood density $(\rho=$ dry weight/green volume in $\mathrm{g} \mathrm{cm}^{-3}$ ) 2-6 wood samples were extracted from the transverse sections of the trunks and branches of each tree (Yepes et al. 2016). All samples were then dried at $105^{\circ} \mathrm{C}$ in a drying oven for $48-72$ hours to a constant weight. The dry weight $(0.01 \mathrm{~g})$ of each component of each species was weighed using an electronic balance. Finally, we obtained the biomass of each component (leaf biomass (LB); branch biomass (BB); stem biomass (SB)); total aboveground biomass (AGB, Table 1); and plant component aboveground biomass as a percentage of the AGB per plant species.

\subsection{Data analysis}

We compared the biomass of aboveground plant components (e.g., leaves, branches, stems, and aboveground parts) with selected independent variables $\left(D, H, C a, D^{2} H\right.$, and $\left.\rho D H\right)$ using graphs and correlation coefficients to determine the nature of the correlation. Correlation analysis indicated that $\mathrm{D}, \mathrm{D}^{2} \mathrm{H}$, and $\rho \mathrm{DH}$ explained most of the biomass variations (Fig. S1).

Linear and nonlinear regression analyses were employed for examining the relationships between aboveground biomass components and the measured variables, including $\mathrm{D}, \mathrm{H}, \mathrm{Ca}, \rho, \mathrm{D}^{2} \mathrm{H}$, and $\rho \mathrm{DH}$, which were performed using the 'basictrendline' Package (Mei et al. 2018). By comparing the regression coefficients $\left(\mathrm{R}^{2}\right)$ and Akaike Information Criterion (AIC) of the regression model (Ruiz-Peinado et al. 2012), the following equations were presented for describing the relationships between the aboveground biomass components:

$W=a x+b(8)$

$W=a x^{2}+b x+c(9)$

$\mathrm{W}=\mathrm{ax} \mathrm{x}^{\mathrm{b}}(10)$

where $W$ is the dependent variable $(L B, B B, S B$, and $A G B), x$ is the independent variable $\left(D, H, C a, \rho, D^{2} H, o r \rho D H\right)$, and $a, b$, and $\mathrm{C}$ are the allometric coefficients. All statistical analyses were performed in $\mathrm{R}$ (version 4.0.4).

\section{Results}

\subsection{Aboveground biomass allocation}

The distribution ratios of the total biomass of leaves, branches, and stems of the six shrub and small tree species were evaluated. Comparatively, these six species allocated the most biomass to stems, with the least biomass in the leaves. In contrast to other species, Dendrobenthamia japonica better reflected this phenomenon; however, the distribution of Acer ginnala in each component was relatively even (Fig. 1).

\subsection{Allometric biomass model}

We employed linear regression and nonlinear regression models to estimate the biomass of each species. The higher $\mathrm{R}^{2}$ and lower AIC values of all optimization models indicated that the model had improved utility. For the species-specific model, the single variable $\mathrm{D}$ and complex variables $\mathrm{D}^{2} \mathrm{H}$ and $\rho \mathrm{DH}$ had the best predictive effects for the biomass of the six species (Table 3). For Acer ginnala, Diospyros rhombifolia, and Dendrobenthamia japonica, $\mathrm{D}^{2} \mathrm{H}$ was the best predictor of SB and AGB $\left(R^{2}=0.858 \sim 0.971\right.$ and $R^{2}=0.908 \sim 0.961 ; P<0.001$, respectively). $D$ had the best predictive effect for the leaf biomass of the five species (R2 $=0.602 \sim 0.93 ; \mathrm{P}<0.001)$ and also performed well for the AGB of Lindera fruticosa and Diospyros rhombifolia $\left(\mathrm{R}^{2}=0.937\right.$ and $\left.\mathrm{R}^{2}=0.892 ; \mathrm{p}<0.001\right)$. For Rhododendron ovatum, $\rho \mathrm{DH}$ accounted for more than $90 \%$ of the variations in the $B B(R=0.904 ; P<0.001), S B(R=0.945 ; P<0.001)$, and $A G B(R=0.961 ; P<0.001)$.

Similar to the species-specific allometric models, $\mathrm{pDH}$ was the best predictor for biomass with the pooled data of all shrub Loading [MathJax]/jax/output/CommonHTML/jax.js inclusion of $\rho$ to the independent variable improved the prediction accuracy of 
the model (Fig. 2). As the best predictor for multi-species aboveground biomass regression models $\rho D H$ explained $80.9 \%$, $85.1 \%, 88.3 \%$, and $89.0 \%$ of the variations of $L B(R=0.809 ; P<0.001), B B(R=0.851 ; P<0.001), S B(R=0.883 ; P<0.001)$, and AGB $(R=0.890 ; P<0.001)$, respectively (Table 3$)$.

\section{Discussion}

During plant growth and development, biomass is accumulated in the form of organic matter through plant photosynthesis, where additional biomass is distributed into the stems to increase their length to obtain more light, toward potentially gaining a competitive advantage over other trees (Nam et al. 2018, Bayen et al. 2020). In this study, the biomass of the stems of six shrub and small tree species exceeded that of the branches and leaves, and accounted for more than $50 \%$ of the total aboveground biomass, except for Acer ginnala, which was consistent with many previous results (Singh et al. 2011, Bayen et al. 2020).

Based on the established six specific species and one mixed species model, $\mathrm{D}, \mathrm{D}^{2} \mathrm{H}$, and $\rho \mathrm{DH}$ were the best factors for forecasting the aboveground biomass of shrubs. As distinct from Vu Thanh Nam's method (2018), we employed a single independent variable (single variable $\mathrm{D}, \mathrm{H}, \mathrm{Ca}, \rho$; compound variables $\mathrm{D}^{2} \mathrm{H}, \rho \mathrm{DH}$ ) as a predictor in the model, which made the process simpler and more convenient in operation. We observed from the optimal model, even though we employed a single variable, that it still had a satisfactory prediction accuracy, and the $\mathrm{R}^{2}$ of all models was $>0.6$ (Table 3 ).

In terms of model fitting accuracy, Ca did not perform well (Table. S1), and was shown to be inconsistent with some research (Conti et al. 2013, She et al. 2015, Yang et al. 2017). This was because, unlike desert shrubs and subtropical grassland plants (She et al. 2015, Bayen et al. 2020), the crown structures of subtropical shrubs and small trees are irregular in their natural state, which translates to a decrease in the capacity of Ca to predict the biomass of shrub branches and leaves (Poorter et al. 2012, Liu et al. 2015). However, the addition of $\mathrm{H}$ to the models developed for the shrubs was reasonable; it improved model accuracy when combined with $\mathrm{D}$ and $\rho$, although the correlation between the $\mathrm{H}$ and biomass was lower than Ca (Table 2, Table 3 and Fig. S1). Consistent with previous studies, $\mathrm{D}^{2} \mathrm{H}$ was one of the best predictors of shrub and small tree biomass (Alvarez et al. 2012, Liu et al. 2015, Dou et al. 2019).

When another variable $(\rho \mathrm{DH})$ was employed to predict biomass, the model was better than $\mathrm{D}$ and $\mathrm{H}$, particularly for shrub mixed multi-species models. According to previous studies, $\rho$ was one of the most important characteristics of tree species, which had obvious differences between various species. We introduced $\rho$ as a predictor directly into the model with reference to previous research methods; however, the results were not satisfactory (Table. S1). Compared with D and H, the intraspecies variation in $\rho$ was negligible and could be regarded as almost constant (Francis et al. 2017, Nelson et al. 2020). Thus, we attempted to create a new combined entity $(\rho \mathrm{DH})$ as a predictor variable.

From the results, the introduction of $\rho$ reduced SEE and increased $R^{2}$, which indicated that the inclusion of $\rho$ enhanced the accuracy of the model, which aligned well with the work of Ali (2015). Many studies have indicated that $\rho$ is an essential factor for improving model accuracy (Yepes et al. 2016, Kebede et al. 2018). Furthermore, it was indicated that $\rho$ had enhanced relevance in mixed models, as it was believed to augment the differences in the physiological structures and functional characteristics of tree species (Xu et al. 2015, Nam et al. 2018). Taking $\rho$ as a portion of the independent variable can reduce the errors caused by $\mathrm{D}$ and $\mathrm{H}$ in the measurement to a certain extent, as well as the influences of morphological differences on the accuracy of multi-species models (Pilli et al. 2006, Zeng et al. 2017).

Comparing the accuracy of a model in estimating the biomass of a component of the same tree species, the allometric model possessed a higher predictive ability for wood organs (stems and branches) than leaves. Some studies attributed the low predictive power of leaf biomass models to the ephemeral nature of leaves and their destruction by herbivores (Roxburgh et al. 2015, Sanquetta et al. 2015, Bayen et al. 2020). The accuracy of the allometric leaf model of evergreen shrubs in this

Loading [MathJax]/jax/output/CommonHTML/jax.js ubs, which appeared to confirm this assumption. 
Due to the difficulties involved with fully excavating the root biomass (particularly fine roots), only the aboveground biomass was considered in our research, which might have translated to limitations in the application of the equations. We acknowledge that our developed models were based on a small number of individual samples (i.e., 32 to 38 individuals per species). Therefore, we do not recommend the use of predictive models for tree species beyond the range of predictor variables, which will likely cause significant errors in the estimated values.

\section{Conclusion}

This study sampled six common subtropical shrubs and small trees to develop an allometric species-specific and multispecies shrub model for biomass organs (e.g., leaves, branches, stems, and total aboveground biomass), where $D, H$, and $\rho$ were employed as easily measurable predictors. Variables that had strong correlations with biomass might be used as basic indicators to establish allometric models. The species-specific allometric models developed in this study, with $\mathrm{D}$ and $\mathrm{D}^{2} \mathrm{H}$ as predictors, accounted for a high variation (60.2-97.1\%) in the AGB of shrubs and small trees.

The inclusion of $\rho$ as a predictive variable improved the accuracy of the multi-species shrub model. Further, $\rho \mathrm{DH}$ played a significant role in the allometric models of specific and multiple species. The good predictive capacities of the allometric equations used in this study might be extended to the allometric models of other tree species. In the absence of a specific allometric equation, the multi-species allometric equation was an appropriate choice (under the condition of confirming the variable range). In contrast to species-specific allometric models, optimal multi-species estimation models also had a fit accuracy for all components and total shrub biomass. This indicated that the multi-species model might expedite the estimation of shrub biomass, which can translate to savings in time and manpower. In short, the results of this investigation might facilitate the rapid non-destructive acquisition of biomass estimates for subtropical shrubs and small trees.

\section{Abbreviations}

H: total height (m); D: stem diameter; Ca: canopy area; $\rho$ : basic wood density; LB: leaf biomass; BB: branch biomass (kg); SB: stem biomass; AGB: aboveground biomass; A.g: Acer ginnala; D.r: Diospyros rhombifolia; R.o: Rhododendron ovatum; C.c: Camellia cuspidate; L.f: Lindera fruticose, D.j: Dendrobenthamia japonica; AIC: Akaike information criterion; SEE: standard error of the estimation; CF: correction factor.

\section{Declarations}

Acknowledgments: The authors would like to thank Yunhua Xu and Yougeng Xu (Forest Station of Qiaomu Township) and Xiaoyu Lu, Mingyuan Gu, Mengyu Zhou, Xinxin Tian, Hong Yu, and Chagjian Qi (Anhui Agricultural University) for their support in the collection of field data and biomass processing,

Authors' Contributions: S.F., H.Y.H.C., and C.F. conceived and designed the study; C.H., Y.M., S.Y., and W.W. collected data; C.H. and H.L. analyzed the data; C.H., C.F., S.F., and H.Y.H.C. wrote the manuscript. All authors agreed to the published version of the manuscript and contributed to revisions. Moreover, no individual who qualified for authorship was excluded.

Funding: This research was supported by the Special Major Science and Technology Project of Anhui Province (18030701187), and the 2020 Annual Graduate Innovation Fund of Anhui Agricultural University (2020YSJ-21).

Availability of data and materials $\square T h e$ datasets used and/or analyzed during the current study are available from the corresponding author on reasonable request.

\section{Ethics approval and consent to participate}

Not applicable

Loading [MathJax]/jax/output/CommonHTML/jax.js 


\section{Consent for publication}

Not applicable

\section{Competing interests}

The authors declare no competing interests.

\section{Author details}

${ }^{1}$ College of Forestry and Landscape Architecture, Anhui Agricultural University, 130 Changjiang West Road, Hefei, Anhui, China 230036

${ }^{2}$ Faculty of Natural Resources Management, Lakehead University, 955 Oliver Road, Thunder Bay, Ontario, Canada P7B 5E1.

\section{References}

1. Ali A, Xu M S, Zhao Y T, Zhang Q Q, Zhou L L, Yang X D ,Yan E R (2015) Allometric biomass equations for shrub and small tree species in subtropical China. Silva Fennica, 49, 1-10.http://dx.doi.org/ 10.14214/sf.1275

2. Alvarez E, Duque A, Saldarriaga J, Cabrera K, Salas G D, del Valle I, Lema A, Moreno F, Orrego S ,Rodriguez L (2012) Tree above-ground biomass allometries for carbon stocks estimation in the natural forests of Colombia. Forest Ecology and Management, 267, 297-308.http://dx.doi.org/10.1016/j.foreco.2011.12.013

3. Bayen P, Noulekoun F, Bognounou F, Lykke A M, Djomo A, Lamers J P A , Thiombiano A (2020) Models for estimating aboveground biomass of four dryland woody species in Burkina Faso, West Africa. Journal of Arid Environments, 180.http://dx.doi.org/ARTN10420510.1016/j.jaridenv.2020.104205

4. Bond-Lamberty B, Wang C , Gower S T (2002) Aboveground and belowground biomass and sapwood area allometric equations for six boreal tree species of northern Manitoba. Canadian Journal of Forest Research-Revue Canadienne De Recherche Forestiere, 32, 1441-1450.http://dx.doi.org/10.1139/X02-063

5. Brantley S T, Schulte M L, Bolstad P V ,Miniat C F (2016) Equations for Estimating Biomass, Foliage Area, and Sapwood of Small Trees in the Southern Appalachians. Forest Science, 62, 414-421.http://dx.doi.org/10.5849/forsci.15-041

6. Brassard B W, Chen HY H, Bergeron Y ,Pare D (2011) Coarse root biomass allometric equations for Abies balsamea, Picea mariana, Pinus banksiana, and Populus tremuloides in the boreal forest of Ontario, Canada. Biomass \& Bioenergy, 35, 4189-4196.http://dx.doi.org/10.1016/j.biombioe.2011.06.045

7. Cairns M A, Lajtha K ,Beedlow P A (2009) Dissolved carbon and nitrogen losses from forests of the Oregon Cascades over a successional gradient. Plant and Soil, 318, 185-196.http://dx.doi.org/10.1007/s11104-008-9828-5

8. Cavanaugh K C, Gosnell J S, Davis S L, Ahumada J, Boundja P, Clark D B, Mugerwa B, Jansen P A, O'Brien T G, Rovero F, Sheil D, Vasquez R ,Andelman S (2014) Carbon storage in tropical forests correlates with taxonomic diversity and functional dominance on a global scale. Global Ecology and Biogeography, 23, 563-

573.http://dx.doi.org/10.1111/geb.12143

9. Cavard X, Bergeron Y, Chen H Y H ,Pare D (2011) Effect of forest canopy composition on soil nutrients and dynamics of the understorey: mixed canopies serve neither vascular nor bryophyte strata. Journal of Vegetation Science, 22, 11051119.http://dx.doi.org/10.1111/j.1654-1103.2011.01311.x

10. Chapagain T R, Sharma R P ,Bhandari S K (2014) Modeling above-ground biomass for three tropical tree species at their juvenile stage. Forest Science and Technology, 10, 51-60.http://dx.doi.org/10.1080/21580103.2013.834277

11. Chaturvedi R K ,Raghubanshi A S (2013) Aboveground biomass estimation of small diameter woody species of tropical dry forest. New Forests, 44, 509-519.http://dx.doi.org/10.1007/s11056-012-9359-z

12. Chave J, Andalo C, Brown S, Cairns M A, Chambers J Q, Eamus D, Folster H, Fromard F, Higuchi N, Kira T, Lescure J P, Loading [MathJax]/jax/output/CommonHTML/jax.js 'amakura T (2005) Tree allometry and improved estimation of carbon stocks and 
balance in tropical forests. Oecologia, 145, 87-99.http://dx.doi.org/10.1007/s00442-005-0100-x

13. Chave J, Rejou-Mechain M, Burquez A, Chidumayo E, Colgan M S, Delitti W B, Duque A, Eid T, Fearnside P M, Goodman R C, Henry M, Martinez-Yrizar A, Mugasha W A, Muller-Landau H C, Mencuccini M, Nelson B W, Ngomanda A, Nogueira E M, Ortiz-Malavassi E, Pelissier R, Ploton P, Ryan C M, Saldarriaga J G, Vieilledent G (2014) Improved allometric models to estimate the aboveground biomass of tropical trees. Global Change Biology, 20, 3177-

90.http://dx.doi.org/10.1111/gcb.12629

14. Conti G, Enrico L, Casanoves F ,Diaz S (2013) Shrub biomass estimation in the semiarid Chaco forest: a contribution to the quantification of an underrated carbon stock. Annals of Forest Science, 70, 515524.http://dx.doi.org/10.1007/s13595-013-0285-9

15. Djomo A N, Ibrahima A, Saborowski J ,Gravenhorst G (2010) Allometric equations for biomass estimations in Cameroon and pan moist tropical equations including biomass data from Africa. Forest Ecology and Management, 260, 18731885.http://dx.doi.org/10.1016/j.foreco.2010.08.034

16. Donato D C, Campbell J L ,Franklin J F (2012) Multiple successional pathways and precocity in forest development: can some forests be born complex? Journal of Vegetation Science, 23, 576-584.http://dx.doi.org/10.1111/j.1654-

1103.2011.01362.x

17. Dou Y X, Yang Y ,An S S (2019) Above-Ground Biomass Models of Caragana korshinskii and Sophora viciifolia in the Loess Plateau, China. Sustainability, 11.http://dx.doi.org/ARTN 1674

18. $10.3390 /$ su11061674

19. Elzein T M, Blarquez $O$, Gauthier $O$,Carcaillet $C$ (2011) Allometric equations for biomass assessment of subalpine dwarf shrubs. Alpine Botany, 121, 129-134.http://dx.doi.org/10.1007/s00035-011-0095-3

20. Flade L, Hopkinson C ,Chasmer L (2020) Allometric Equations for Shrub and Short-Stature Tree Aboveground Biomass within Boreal Ecosystems of Northwestern Canada. Forests, 11.http://dx.doi.org/ARTN 1207

21. 10. 3390/f11111207

22. Francis E J, Muller-Landau H C, Wright S J, Visser M D, lida Y, Fletcher C, Hubbell S P ,Kassim A (2017) Quantifying the role of wood density in explaining interspecific variation in growth of tropical trees. Global Ecology and Biogeography, 26, 1078-1087.http://dx.doi.org/10.1111/geb.12604

23. Huff S, Poudel K P, Ritchie M ,Temesgen H (2018) Quantifying aboveground biomass for common shrubs in northeastern California using nonlinear mixed effect models. Forest Ecology and Management, 424, 154163.http://dx.doi.org/10.1016/j.foreco.2018.04.043

24. IUSS Working Group WRB. 2014. World reference base for soil resources 2014. International soil classification system for naming soils and creating legends for soil maps. FAO, Rome, Italy.

25. Jagodzinski A M, Dyderski M K, Gesikiewicz K,Horodecki P (2019) Tree and stand level estimations of Abies alba Mill. aboveground biomass. Annals of Forest Science, 76, 14.http://dx.doi.org/ARTN 56

26. 10. 1007/s13595-019-0842-y

27. Kebede B ,Soromessa T (2018) Allometric equations for aboveground biomass estimation of Olea europaea L. subsp cuspidata in Mana Angetu Forest. Ecosystem Health and Sustainability, 4, 112.http://dx.doi.org/10.1080/20964129.2018.1433951

28. Kumar P, Chen H Y H, Searle E B ,Shahi C (2018) Dynamics of understorey biomass, production and turnover associated with long-term overstorey succession in boreal forest of Canada. Forest Ecology and Management, 427, 152161.http://dx.doi.org/10.1016/j.foreco.2018.05.066

29. Liu Z W, Chen R S, Song Y X, Han C T , Yang Y (2015) Estimation of aboveground biomass for alpine shrubs in the upper reaches of the Heihe River Basin, Northwestern China. Environmental Earth Sciences, 73, 55135521.http://dx.doi.org/10.1007/s12665-014-3805-5

Loading [MathJax]/jax/output/CommonHTML/jax.js 
30. MacDonald R L, Burke J M, Chen H Y H ,Prepas E E (2012) Relationship between Aboveground Biomass and Percent Cover of Ground Vegetation in Canadian Boreal Plain Riparian Forests. Forest Science, 58, 47-

53.http://dx.doi.org/10.5849/forsci.10-129

31. Mbow C, Verstraete M M, Sambou B, Diaw A T ,Neufeldt H (2014) Allometric models for aboveground biomass in dry savanna trees of the Sudan and Sudan-Guinean ecosystems of Southern Senegal. Journal of Forest Research, 19, 340347.http://dx.doi.org/10.1007/s10310-013-0414-1

32. Mei W, Yu G, Lai J, Rao Q ,Umezawa Y (2018) basicTrendline: Add Trendline and Confidence Interval of Basic Regression Models to Plot.

33. Nam V T, Anten N P R , van Kuijk M (2018) Biomass dynamics in a logged forest: the role of wood density. Journal of Plant Research, 131, 611-621.http://dx.doi.org/10.1007/s10265-018-1042-9

34. Nelson R A, Francis E J, Berry J A, Cornwell W K ,Anderegg L D L (2020) The Role of Climate Niche, Geofloristic History, Habitat Preference, and Allometry on Wood Density within a California Plant Community. Forests, 11.http://dx.doi.org/ARTN 105

35. 10. 3390/f11010105

36. Paul K I, Roxburgh S H, England J R, Ritson P, Hobbs T, Brooksbank K, Raison R J, Larmour J S, Murphy S, Norris J, Neumann C, Lewis T, Jonson J, Carter J L, McArthur G, Barton C ,Rose B (2013) Development and testing of allometric equations for estimating above-ground biomass of mixed-species environmental plantings. Forest Ecology and Management, 310, 483-494.http://dx.doi.org/10.1016/j.foreco.2013.08.054

37. Pilli R, Anfodillo T ,Carrer M (2006) Towards a functional and simplified allometry for estimating forest biomass. Forest Ecology and Management, 237, 583-593.http://dx.doi.org/10.1016/j.foreco.2006.10.004

38. Poorter H, Niklas K J, Reich P B, Oleksyn J, Poot P ,Mommer L (2012) Biomass allocation to leaves, stems and roots: meta-analyses of interspecific variation and environmental control. New phytologist, 193, 3050.http://dx.doi.org/10.1111/j.1469-8137.2011.03952.x

39. Roxburgh S H, Paul K I, Clifford D, England J R ,Raison R J (2015) Guidelines for constructing allometric models for the prediction of woody biomass: How many individuals to harvest? Ecosphere, 6, 1-27.http://dx.doi.org/10.1890/es1400251.1

40. Ruiz-Peinado R, Montero G, del Rio M (2012) Biomass models to estimate carbon stocks for hardwood tree species. Forest Systems, 21, 42-52.http://dx.doi.org/10.5424/fs/2112211-02193

41. Sanquetta C R, Behling A, Corte A P D, Péllico Netto S, Schikowski A B , do Amaral M K (2015) Simultaneous estimation as alternative to independent modeling of tree biomass. Annals of Forest Science, 72, 1099-

1112.http://dx.doi.org/10.1007/s13595-015-0497-2

42. Sharma R P, Brunner A, Eid T ,Oyen B H (2011) Modelling dominant height growth from national forest inventory individual tree data with short time series and large age errors. Forest Ecology and Management, 262, 21622175.http://dx.doi.org/10.1016/j.foreco.2011.07.037

43. She W W, Zhang Y Q, Qin S G, Wu B, Liu Z, Liu J ,Zhang W J (2015) Habitat Effect on Allometry of a Xeric Shrub (Artemisia ordosica Krasch) in the Mu Us Desert of Northern China. Forests, 6, 45294539.http://dx.doi.org/10.3390/f6124385

44. Singh V, Tewari A, Kushwaha S P S ,Dadhwal V K (2011) Formulating allometric equations for estimating biomass and carbon stock in small diameter trees. Forest Ecology and Management, 261, 19451949.http://dx.doi.org/10.1016/j.foreco.2011.02.019

45. Xu Y Z, Zhang J X, Franklin S B, Liang J Y, Ding P, Luo Y Q, Lu Z J, Bao D C , Jiang M X (2015) Improving allometry models to estimate the above- and belowground biomass of subtropical forest, China. Ecosphere, 6 , 15.http://dx.doi.org/Artn 289

46. 10. 1890/Es15-00198.1

Loading [MathJax]/jax/output/CommonHTML/jax.js 
47. Yang H T, Wang Z R, Tan H J ,Gao Y H (2017) Allometric models for estimating shrub biomass in desert grassland in northern China. Arid Land Research and Management, 31, 283-300.http://dx.doi.org/10.1080/15324982.2017.1301595

48. Yang S, Feng C, Ma Y, Wang W, Huang C, Qi C, Fu S ,Chen H Y H (2021) Transition from N to P limited soil nutrients over time since restoration in degraded subtropical broadleaved mixed forests. Forest Ecology and Management, 494, 119298.http://dx.doi.org/10.1016/j.foreco.2021.119298

49. Yepes A, Zapata M, Bolivar J, Monsalve A, Espinosa S M, Sierra-Correa P C ,Sierra A (2016) [Tree above-ground biomass allometries for carbon stocks estimation in the Caribbean mangroves in Colombia]. Revista de Biologia Tropical 64, 913 - 26.http://dx.doi.org/10.15517/rbt.v64i2.18141

50. Yu G, Chen Z, Piao S, Peng C, Ciais P, Wang Q, Li X ,Zhu X (2014) High carbon dioxide uptake by subtropical forest ecosystems in the East Asian monsoon region. Proc Natl Acad Sci U S A, 111, 4910-

5.http://dx.doi.org/10.1073/pnas.1317065111

51. Zeng W S, Duo H R, Lei X D, Chen X Y, Wang X J, Pu Y ,Zou W T (2017) Individual tree biomass equations and growth models sensitive to climate variables for Larix spp. in China. European Journal of Forest Research, 136, 233249.http://dx.doi.org/10.1007/s10342-017-1024-9

\section{Tables}

Table 1. Summary of the range values (min-max) of biometric variables of the six woody species.

\begin{tabular}{|c|c|c|c|c|c|c|c|c|c|}
\hline Species & $\mathrm{n}$ & $\mathrm{D}(\mathrm{cm})$ & $\mathrm{H}(\mathrm{m})$ & $\begin{array}{l}\mathrm{Ca} \\
\left(\mathrm{m}^{2}\right)\end{array}$ & $\rho\left(\mathrm{g} / \mathrm{cm}^{3}\right)$ & LB $(\mathrm{kg})$ & BB $(\mathrm{kg})$ & SB (kg) & $\begin{array}{l}\text { AGB } \\
(\mathrm{kg})\end{array}$ \\
\hline Acer ginnala & 32 & $\begin{array}{l}0.42- \\
4.03\end{array}$ & $\begin{array}{l}0.84- \\
4.60\end{array}$ & $\begin{array}{l}0.02- \\
2.79\end{array}$ & $0.51(0.01)$ & $\begin{array}{l}0.001- \\
0.167\end{array}$ & $\begin{array}{l}0.003- \\
0.343\end{array}$ & $\begin{array}{l}0.001- \\
0.397\end{array}$ & $\begin{array}{l}0.003- \\
0.884\end{array}$ \\
\hline $\begin{array}{l}\text { Diospyros } \\
\text { rhombifolia }\end{array}$ & 35 & $\begin{array}{l}0.60- \\
2.45\end{array}$ & $\begin{array}{l}1.04- \\
3.78\end{array}$ & $\begin{array}{l}0.03- \\
2.24\end{array}$ & $0.55(0.01)$ & $\begin{array}{l}0.004- \\
0.062\end{array}$ & $\begin{array}{l}0.001- \\
0.291\end{array}$ & $\begin{array}{l}0.009- \\
0.411\end{array}$ & $\begin{array}{l}0.015- \\
0.760\end{array}$ \\
\hline $\begin{array}{l}\text { Rhododendron } \\
\text { ovatum }\end{array}$ & 36 & $\begin{array}{l}0.99- \\
4.79\end{array}$ & $\begin{array}{l}1.42- \\
3.47\end{array}$ & $\begin{array}{l}0.10- \\
2.26\end{array}$ & $0.65(0.01)$ & $\begin{array}{l}0.009- \\
0.177\end{array}$ & $\begin{array}{l}0.011- \\
0.509\end{array}$ & $\begin{array}{l}0.027- \\
0.887\end{array}$ & $\begin{array}{l}0.056- \\
1.563\end{array}$ \\
\hline Camellia cuspidata & 33 & $\begin{array}{l}0.81- \\
4.93\end{array}$ & $\begin{array}{l}0.72- \\
4.90\end{array}$ & $\begin{array}{l}0.11- \\
6.18\end{array}$ & $0.70(0.02)$ & $\begin{array}{l}0.007- \\
0.516\end{array}$ & $\begin{array}{l}0.006- \\
1.076\end{array}$ & $\begin{array}{l}0.017- \\
1.607\end{array}$ & $\begin{array}{l}0.031- \\
3.120\end{array}$ \\
\hline $\begin{array}{l}\text { Lindera } \\
\text { fruticosa }\end{array}$ & 38 & $\begin{array}{l}0.24- \\
2.57\end{array}$ & $\begin{array}{l}0.51- \\
4.23\end{array}$ & $\begin{array}{l}0.02- \\
4.54\end{array}$ & $0.39(0.02)$ & $\begin{array}{l}0.002- \\
0.097\end{array}$ & $\begin{array}{l}0.001- \\
0.235\end{array}$ & $\begin{array}{l}0.001- \\
0.354\end{array}$ & $\begin{array}{l}0.002- \\
0.678\end{array}$ \\
\hline $\begin{array}{l}\text { Dendrobenthamia } \\
\text { japonica }\end{array}$ & 33 & $\begin{array}{l}1.35- \\
5.82\end{array}$ & $\begin{array}{l}2.05- \\
7.23\end{array}$ & $\begin{array}{l}0.17- \\
7.69\end{array}$ & $0.43(0.01)$ & $\begin{array}{l}0.005- \\
0.451\end{array}$ & $\begin{array}{l}0.015- \\
0.739\end{array}$ & $\begin{array}{l}0.044- \\
2.369\end{array}$ & $\begin{array}{l}0.081- \\
3.560\end{array}$ \\
\hline
\end{tabular}

Note: $n$, number of individuals per species; $H$, total height $(m)$; $D$, stem diameter $(\mathrm{cm})$; Ca, canopy area $\left(\mathrm{m}^{2}\right) ; \rho$, basic wood density $\left(\mathrm{g} / \mathrm{m}^{3}\right)$; LB, leaf biomass $(\mathrm{kg})$; $B B$, branch biomass $(\mathrm{kg})$; SB, stem biomass $(\mathrm{kg})$; AGB, measurement of all aboveground biomass $(\mathrm{kg})$. Values in brackets represent the standard deviation (SD).

Table 2. Best fit species-specific regression models for the prediction of the aboveground biomass. 


\begin{tabular}{|c|c|c|c|c|c|c|c|c|c|c|}
\hline Species & Variate & Equations & $x$ & a & b & c & $\mathrm{R}^{2}$ & AIC & SEE & CF \\
\hline \multirow[t]{4}{*}{ Acer ginnala } & LB & $Y=a x^{b}$ & $\rho \mathrm{DH}$ & 0.0107 & 1.2995 & & $0.717^{\star \star \star}$ & -144 & 0.0241 & 1.000 \\
\hline & BB & $Y=a x^{b}$ & $\rho \mathrm{DH}$ & 0.0281 & 1.2997 & & $0.883^{\star \star \star}$ & -113 & 0.039 & 1.000 \\
\hline & SB & $Y=a x^{b}$ & $\mathrm{D}^{2} \mathrm{H}$ & 0.0127 & 0.8865 & & $0.905^{\star \star \star}$ & -118 & 0.0357 & 1.000 \\
\hline & AGB & $\begin{array}{l}Y= \\
a x^{2}+b x+c\end{array}$ & $D^{2} \mathrm{H}$ & -0.0002 & 0.0264 & 0.0014 & $0.908^{\star \star \star}$ & -64 & 0.0823 & 1.003 \\
\hline \multirow{4}{*}{$\begin{array}{l}\text { Diospyros } \\
\text { rhombifolia }\end{array}$} & LB & $Y=a x+b$ & $\mathrm{D}$ & 0.0269 & 0.0115 & & $0.602^{\star \star}$ & -216 & 0.0105 & 1.000 \\
\hline & BB & $Y=a x^{b}$ & $\mathrm{D}$ & 0.0258 & 2.3461 & & $0.762^{\star \star \star}$ & -138 & 0.032 & 1.001 \\
\hline & SB & $Y=a x+b$ & $D^{2} \mathrm{H}$ & 0.0204 & 0.0067 & & $0.858^{\star \star \star}$ & -120 & 0.0413 & 1.001 \\
\hline & AGB & $Y=a x^{b}$ & $\mathrm{D}$ & 0.0855 & 2.3190 & & $0.892^{\star \star \star}$ & -95 & 0.0592 & 1.001 \\
\hline \multirow{4}{*}{$\begin{array}{l}\text { Rhododendron } \\
\text { ovatum }\end{array}$} & LB & $Y=a x+b$ & $\mathrm{D}$ & 0.0411 & -0.0360 & & $0.753^{\star \star \star}$ & -172 & 0.0196 & 1.000 \\
\hline & BB & $\begin{array}{l}Y= \\
a x^{2}+b x+c\end{array}$ & $\rho \mathrm{DH}$ & -0.0011 & -0.0622 & -0.0584 & $0.904^{\star \star \star}$ & -131 & 0.0348 & 1.001 \\
\hline & SB & $\begin{array}{l}Y= \\
a x^{2}+b x+c\end{array}$ & $\rho \mathrm{DH}$ & -0.0013 & 0.1041 & -0.0843 & $0.945^{\star \star \star}$ & -111 & 0.0461 & 1.001 \\
\hline & AGB & $\begin{array}{l}Y= \\
a x^{2}+b x+c\end{array}$ & $\rho \mathrm{DH}$ & -0.0026 & 0.1850 & -0.1480 & $0.961^{\star \star \star}$ & -86 & 0.0662 & 1.002 \\
\hline \multirow{4}{*}{$\begin{array}{l}\text { Camellia } \\
\text { cuspidate }\end{array}$} & LB & $Y=a x^{b}$ & D & 0.0222 & 2.0255 & & $0.930^{\star \star \star}$ & -117 & 0.0385 & 1.001 \\
\hline & BB & $\begin{array}{l}Y= \\
a x^{2}+b x+c\end{array}$ & $\rho \mathrm{DH}$ & -0.0018 & 0.0970 & -0.1205 & $0.868^{\star \star \star}$ & -47 & 0.0110 & 1.006 \\
\hline & SB & $\begin{array}{l}Y= \\
a x^{2}+b x+c\end{array}$ & $\mathrm{D}^{2} \mathrm{H}$ & -0.0001 & 0.0263 & 0.0048 & $0.952^{\star \star}$ & -53 & 0.1010 & 1.005 \\
\hline & AGB & $\begin{array}{l}Y= \\
a x^{2}+b x+c\end{array}$ & $\mathrm{D}^{2} \mathrm{H}$ & -0.0002 & 0.0533 & -0.0199 & $0.947^{\star \star \star}$ & -5 & 0.2080 & 1.022 \\
\hline \multirow[t]{4}{*}{ Lindera fruticosa } & LB & $Y=a x+b$ & $\mathrm{D}$ & 0.0432 & 0.0212 & & $0.680^{\star \star \star}$ & -213 & 0.0139 & 1.001 \\
\hline & BB & $Y=a x^{b}$ & $D$ & 0.0192 & 2.6443 & & $0.913^{\star \star \star}$ & -207 & 0.015 & 1.000 \\
\hline & SB & $Y=a x^{b}$ & $\mathrm{D}^{2} \mathrm{H}$ & 0.0359 & 0.7234 & & $0.925^{\star \star \star}$ & -178 & 0.022 & 1.000 \\
\hline & AGB & $\begin{array}{l}Y= \\
a x^{2}+b x+c\end{array}$ & $\mathrm{D}$ & 0.0774 & 0.0786 & -0.0530 & $0.937^{\star \star \star}$ & -136 & 0.0379 & 1.001 \\
\hline \multirow{4}{*}{$\begin{array}{l}\text { Dendrobenthamia } \\
\text { japonica }\end{array}$} & LB & $Y=a x^{b}$ & $\mathrm{D}$ & 0.0057 & 2.4503 & & $0.862^{\star \star \star}$ & -127 & 0.0333 & 1.001 \\
\hline & BB & $Y=a x^{b}$ & $\mathrm{D}^{2} \mathrm{H}$ & 0.0118 & 0.7686 & & $0.861^{\star \star \star}$ & -79 & 0.0686 & 1.002 \\
\hline & SB & $Y=a x^{b}$ & $\mathrm{D}^{2} \mathrm{H}$ & 0.0267 & 0.8168 & & $0.971^{\star \star \star}$ & -66 & 0.0844 & 1.004 \\
\hline & AGB & $Y=a x^{b}$ & $D^{2} \mathrm{H}$ & 0.0420 & 0.8099 & & $0.962^{\star \star \star}$ & -28 & 0.1490 & 1.011 \\
\hline
\end{tabular}

Note: $\mathrm{H}$, total height; $\mathrm{D}$, diameter of the longest stem; $\rho$, wood density; LB, leaf biomass; BB, branch biomass; SB, stem Loading [MathJax]/jax/output/CommonHTML/jax.js a, b, c, allometric coefficients; $\mathrm{R}^{2}$, coefficient of determination; AIC, Akaike 
information criterion; SEE, standard error of the estimation; CF, correction factor. ${ }^{* \star}, \mathrm{p}<0.001 ;{ }^{* \star}, \mathrm{p}<0.01$

Table 3. Best fitted multi-species regression models for the prediction of aboveground biomass.

\begin{tabular}{|c|c|c|c|c|c|c|c|c|c|}
\hline Species & Variety & Equations & $x$ & a & $\mathrm{b}$ & $\mathrm{R}^{2}$ & AIC & SEE & $\mathrm{CF}$ \\
\hline \multirow[t]{4}{*}{ Multi-species } & LB & $Y=a x^{b}$ & $\rho \mathrm{DH}$ & 0.0132 & 1.3146 & $0.809^{\star \star}$ & -674 & 0.034 & 1.001 \\
\hline & BB & $Y=a x^{b}$ & $\rho \mathrm{DH}$ & 0.0338 & 1.2282 & $0.851^{\star \star \star}$ & -461 & 0.063 & 1.001 \\
\hline & SB & $Y=a x^{b}$ & $\rho \mathrm{DH}$ & 0.0523 & 1.2398 & $0.883^{\star \star \star}$ & -357 & 0.085 & 1.005 \\
\hline & AGB & $Y=a x^{b}$ & $\rho \mathrm{DH}$ & 0.0994 & 1.2464 & $0.890^{\star \star \star}$ & -140 & 0.160 & 1.013 \\
\hline
\end{tabular}

Note: $\mathrm{H}$, total height; $\mathrm{D}$, diameter of the longest stem; $\rho$, wood density; LB, leaf biomass; BB, branch biomass; SB, stem biomass; AGB, total aboveground biomass; $a$, b, allometric coefficients; $R^{2}$, coefficient of determination; AIC, Akaike information criterion; SEE, standard error of the estimation; $C F$, correction factor. ${ }^{\star \star \star}, p<0.001$

\section{Figures}

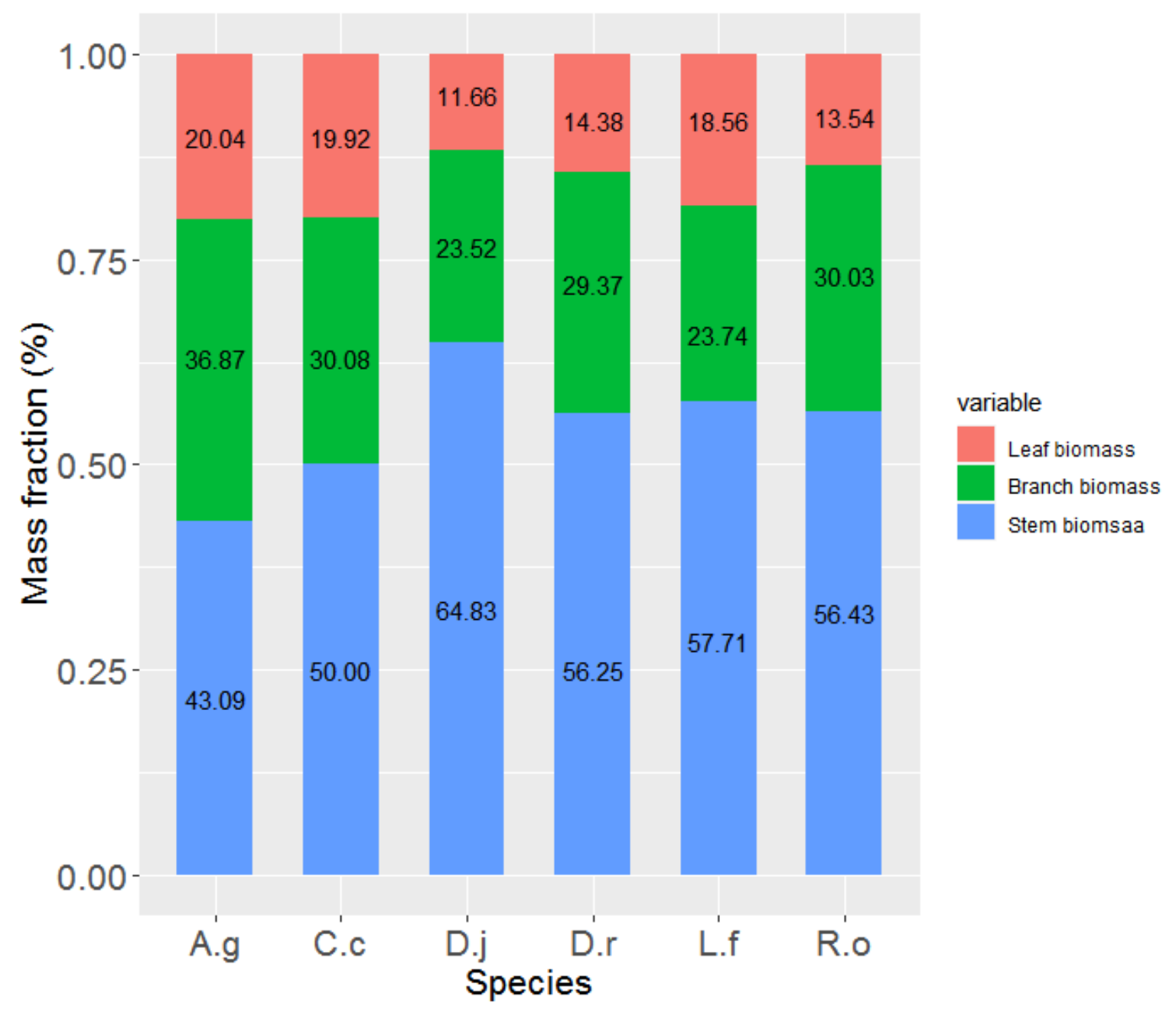

Figure 1 
Aboveground biomass allocation (\%) of branches, leaves, and stems in the six shrub and tree species. A.g (Acer ginnala), D.r (Diospyros rhombifolia); R.o (Rhododendron ovatum); C.c (Camellia cuspidata); L.f (Lindera fruticosa); D.j (Dendrobenthamia japonica). Values are means $\pm 95 \%$ bootstrapped confidence intervals.
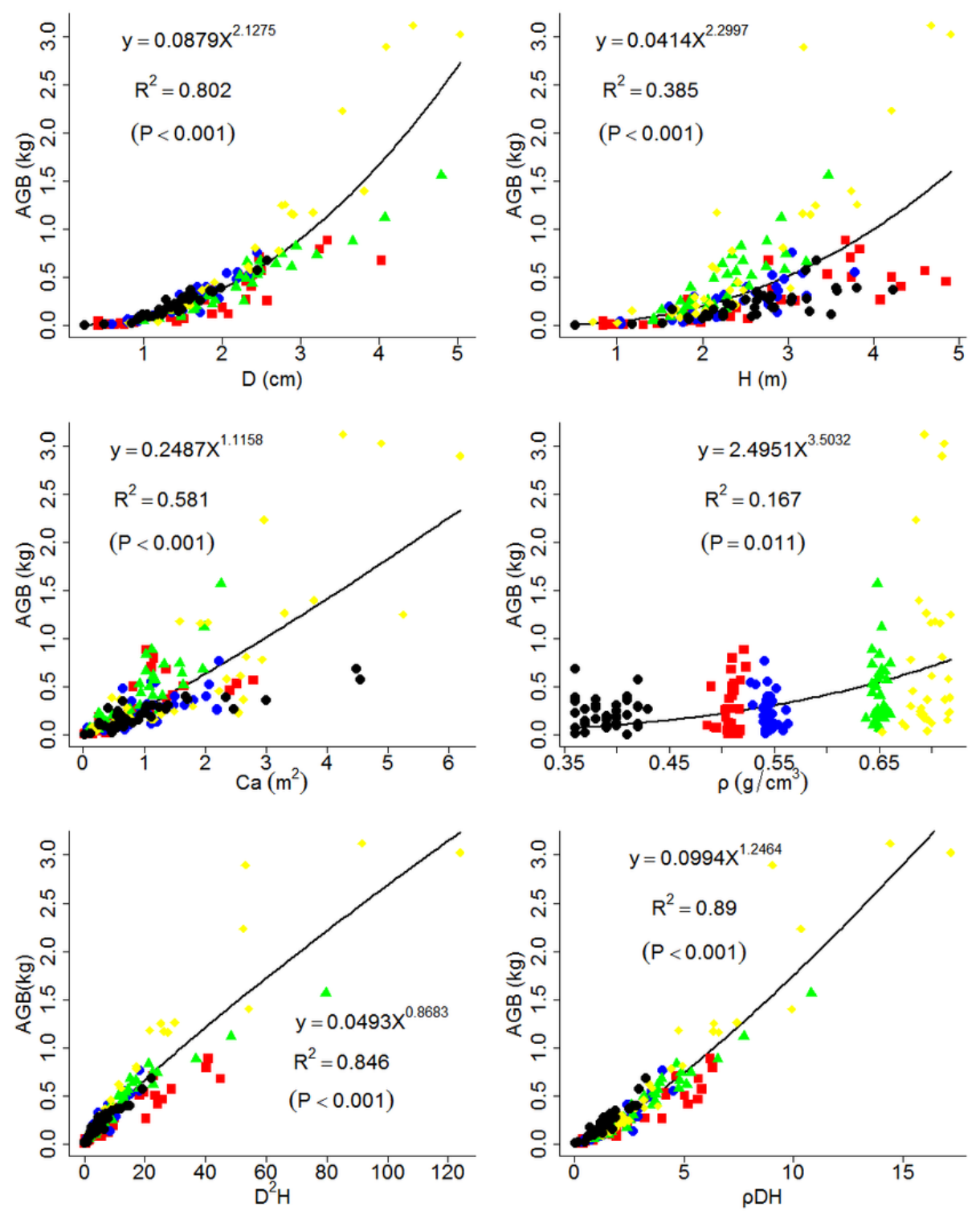

- Acer ginnala

Camellia cuspidata

- Diospyros rhombifolia

- Lindera fruticosa

Rhododendron ovatum

Figure 2

Relationship between ABG (the total aboveground biomass), D (diameter of the longest stem), $\mathrm{H}$ (height), Ca (crown area), $\mathrm{D} 2 \mathrm{H}$, and $\rho \mathrm{DH}$ for the six selected shrub and small tree species. Different symbols represent individual species, whereas the trend line represents the power function $(Y=a x b)$.

\section{Supplementary Files}

This is a list of supplementary files associated with this preprint. Click to download. 
- SupplementaryInformation.docx 